\title{
Disodium Pentaborate Decahydrate up-regulates expressions of MAP kinase genes in human prostate cancer cells
}

\author{
Prostat kanseri hücrelerinde MAP kinaz gen ekspresyonlarını yukarı doğru regüle eden \\ disodyum pentaborat dekahidrat
}

\author{
Çığır Biray Avcı, ${ }^{1}$ Burcu Erbaykent Tepedelen, ${ }^{2}$ Özgün Özalp, ${ }^{1}$ Bakiye Göker Bağca, ${ }^{1}$ Yavuz Dodurga, ${ }^{3}$ \\ Duygu Aygüneş, ${ }^{1}$ Nur Selvi Günel, ${ }^{1}$ Mehmet Korkmaz, ${ }^{4}$ Cumhur Gündüz ${ }^{1}$ \\ ${ }^{1}$ Department of Medical Biology, Medical Faculty of Ege University, Izmir, Turkey \\ ${ }^{2}$ Department of Molecular Biology and Genetic, Avrasya University, Faculty of Science and Letter, Trabzon, Turkey \\ ${ }^{3}$ Department of Medical Biology, Medical Faculty of Pamukkale University, Denizli, Turkey \\ ${ }^{4}$ Department of Medical Biology, Medical Faculty of Celal Bayar University, Manisa, Turkey
}

\begin{abstract}
Objectives: This study aims to investigate the expressions of MAP2K3, MAP3K7, and MAPK8 genes after disodium pentaborate decahydrate (DPD) treatment in DU-145 cells.

Materials and methods: Effect of DPD treatment on expressions of MAP2K3, MAP3K7, and MAPK8 genes were determined by qRT-PCR.

Results: We determined that disodium pentaborate decahydrate treatment increased the expressions of MAP2K3, MAP3K7, and MAPK8 genes in terms of mRNA levels.

Conclusion: The reason of increased apoptosis might be associated with high expression levels of MAP2K3, MAP3K7, and MAPK8 genes after DPD treatment. Our novel findings suggest that DPD may be an important agent in the treatment of prostate cancer by inducing apoptosis against mitogenic and environmental stress.

Keywords: Disodium pentaborate decahydrate; gene expression; prostate cancer.
\end{abstract}

ÖZ

Amaç: Bu çalışmada DU-145 hücrelerinde disodyum pentaborat dekahidrat (DPD) uygulamasının ardından MAP2K3, MAP3K7 ve MAPK8 genlerinin ekspresyonları araştırıldı.

Gereç ve yöntemler: Disodyum pentaborat dekahidrat uygulamasının MAP2K3, MAP3K7 ve MAPK8 genlerinin ekspresyonlarına olan etkisi qRT-PCR ile belirlendi.

Bulgular: Disodyum pentaborat dekahidrat uygulamasının MAP2K3, MAP3K7 ve MAPK8 genlerinin mRNA seviyelerini artırdığı belirlendi.

Sonuç: Apoptoz artışının, MAP2K3, MAP3K7 ve MAPK8 genlerinin DPD uygulaması sonrasında yükselen ekspresyon seviyelerine bağlı olarak gerçekleştiği düşünülmektedir. Güncel bulgularımız DPD'nin prostat kanseri tedavisinde mitojenik ve çevresel strese karşı apoptoza neden olan önemli bir etken olabileceğini öngörmektedir.

Anahtar sözcükler: Disodyum pentaborat dekahidrat; gen ekspresyonu; prostat kanseri.

Prostate cancer is the most common type of cancer and the second leading cause of cancer related death among the male population. ${ }^{[1]}$ It is estimated that approximately half of all male cancer patients are diagnosed with prostate cancer in the USA. ${ }^{[2]}$
Prostate cancer is usually androgen dependent but the tumor can relapse and become more aggressive and also androgen independent after therapy. In this situation, prostate cancer exhibits metastatic progression and becomes resistant to 
hormonal manipulation. ${ }^{[3,4]}$ Androgens, including testosterone and its derivative dihydrotestosterone, are sex hormones which are required for the growth and maintenance of prostate tissue..$^{[5]}$ In the absence of ligand, androgen receptor (AR) is located in the cytoplasm as a complex with heat shock proteins, cytoskeletal proteins and other chaperones. After binding androgens to AR, there is a conformational change in this complex which induces translocation of AR to the nucleus. ${ }^{[5]}$ In the nucleus, AR binds to androgen response elements and enhances expression of target genes such as prostate specific antigen (PSA). ${ }^{[5]}$ Anti-androgens, luteinizing hormone-releasing hormone (LHRH) agonists, and also steroid biosynthesis pathway inhibitors have been used for prostate cancer treatment prior to chemotherapy or combined with chemotherapy, because androgen signaling pathway is crucial in terms of survival of prostate cancer patients and prostate cancer stages. ${ }^{[6,7]}$ Although AR signaling pathway is used as a target in prostate cancer treatment, drugs that are used to treat tumors might not be sufficient due to reasons such as the heterogeneity of these tumors. The expected benefits could not be gained from antihormone treatments today due to the limitations of traditional androgen deprivation therapy. ${ }^{[7]}$

Increased groundwater boron concentrations are associated with a decrease in incidences of prostate cancer and mortality rates. ${ }^{[8]}$ Dietary intake of boron is known to be important for decreasing the risk of prostate cancer in a dose responsive manner. ${ }^{[9]}$ It is known that boric acid, a soluble form of boron, inhibits cell proliferation in hormone dependent and independent prostate cancer cell lines. ${ }^{[10]}$ Effects of boric acid on cell proliferation are more efficient in a hormone independent manner on prostate cancer cells than normal prostate and hormone dependent prostate cancer cells although boric acid reduces cell proliferation in normal prostate and hormone dependent prostate cancer cells. ${ }^{[10]}$ It is shown that prolonged boric acid treatment changes cellular morphology of DU-145 prostate cancer cells via cytoskeleton alterations and inhibits cell attachment, migration and invasion. ${ }^{[11]}$ Prolonged boric acid treatment also decreases expression of cyclins and the phosphorylated form of MEK in the DU-145 prostate cancer cell line. ${ }^{[1]}$ Furthermore, boric acid triggers senescence and its characteristics in DU-145 in a dose dependent manner. ${ }^{[1]}$ In addition to the cellular functions of boric acid, comparative analysis indicates that another boron derivative component, phenylboronic acid, is more effective than boric acid on prostate cancer cells. ${ }^{[12]}$ Due to this reason, using different derivatives of boron might be important to finding a candidate agent for prostate cancer treatment.

Expression of mitogen-activated protein kinase kinase 3 (MAP2K3) is downregulated in immortal human breast epithelial cells but upregulation of MAP2K3 expression provides cell senescence. ${ }^{[13]}$ Detachment of MCF-10A mammary epithelial cells induces MAP2K3 and MAP2K6 expressions and this induction promotes anoikis via $\mathrm{p} 38 \alpha$ signaling pathway. ${ }^{[14]}$ It has been demonstrated that MAP2K3 is activated by induced apoptosis with FTY720 in prostate cancer. ${ }^{[15]}$ The time dependent activation of MAP2K3 is associated with the induction of apoptosis via caspase signaling in DU-145 prostate cancer cells. ${ }^{[15]}$ Heterozygous MAP3K7 gene deletions were identified in prostate cancers and MAP3K7 deletions were associated with advanced stage tumor and lymph node metastasis. ${ }^{[16]}$ Because one allele of MAP3K7 is deleted in prostate cancer, it is thought that MAP3K7 is a tumor suppressor gene for prostate cancer. ${ }^{[16,17]}$ High expression of the MAPK8 gene leads to caspase 8 cleavages for apoptosis in prostate cancer. ${ }^{[18]}$

It is known that disodium pentaborate decahydrate (DPD) induces apoptosis in DU-145 prostate cancer cells. ${ }^{[19]}$ In this study, we aimed to detect expressions of MAP2K3, MAP3K7, and MAPK8 genes in DU-145 cells after DPD treatment. Then, we found that expressions of the MAP2K3, MAP3K7, and MAPK8 genes were increased in terms of messenger ribonucleic acid (mRNA) levels after DPD treatment. This data indicates that DPD can play a role in the regulation of apoptosis through the MAPK pathway due to the function of the MAPK8, MAP3K7 and MAP2K3 genes in the cellular response and apoptosis against mitogenic and environmental stress.

\section{MATERIALS AND METHODS}

\section{Cell culture}

Hormone-independent human prostate cancer cell line DU145 was purchased from the American 
Type Culture Collection (ATCC). DU145 cells (passage numbers 10-20) were propagated in DMEM HAM'S-F12 (Invitrogen, Paisley, UK) medium supplemented with 10\% FBS (Invitrogen, Paisley, UK), 1\% L-glutamine and 1\% penicillinstreptomycin in a humidified incubator at $37{ }^{\circ} \mathrm{C}$ $5 \% \mathrm{CO}_{2}$. When the cells reach confluence, they were removed from cell culture plates with trypsin-EDTA solution and subcultured for further experiments.

\section{Cell treatment}

According to our previous study, ${ }^{[19]}$ DU-145 cells were treated with $7 \mathrm{mM}$ DPD before gene expression analysis. We used $7 \mathrm{mM}$ DPD in this study because $7 \mathrm{mM}$ DPD concentration exhibits the maximum cytotoxic effect without time conditions (24, 48, and 72 hours) and induces apoptosis in DU-145 cells. ${ }^{[19]}$ Control cells were incubated under same conditions without DPD.

\section{Total RNA isolation}

To evaluate gene expression, a total RNA isolation was conducted to extract RNA from the DU145 cell line by using RNeasy Mini Kit (Qiagen, Hilden, Germany) according to the manufacturer's protocol. Total RNA was isolated from DU145 prostate cancer cells which were untreated and treated with $7 \mathrm{mM}$ DPD for 24 hour.

\section{Reverse transcriptase RT-PCR}

Complementary DNA (cDNA) synthesis was performed with the total RNAs obtained from untreated and treated DU145 prostate cancer cells. RT ${ }^{2}$ First Strand Kit (Roche Diagnostics, Germany) was used for cDNA synthesis, from cell lines as first step of reverse transcription. Custom RT ${ }^{2}$ PCR Array (Roche Diagnostics, Germany) was used to evaluate the quantitative gene expression analysis of 48 genes including MAP2K3, MAP3K7, MAPK8, and housekeeping genes with LightCycler 480 qRT-PCR system. The expression values of these genes were proportioned to housekeeping genes (18S ribosomal RNA and GAPDH) to calculate the relative expression ratios. Data analysis was carried using the $\Delta \Delta^{\mathrm{CT}}$ method and quantitated by "LightCycler 480 Quantification Software" and statistical analysis was evaluated by web based $\mathrm{RT}^{2}$ Profiler PCR Array Data Analysis version 3.5. The $p$ value calculation was based on a Student's $t$ test of the replicate $2^{\wedge}$ (- Delta Ct) values for each gene in the control and treatment groups. A value of $p<0.05$ was considered as significant.

\section{RESULTS}

Expressions of MAP2K3, MAP3K7, and MAPK8 genes were detected by qRT-PCR. Relative quantification method was used for data analysis. GADPH and 18S ribosomal RNA were used as internal normalization factor and DPD untreated DU-145 cells were determined as external normalization factor. According to previous IC50 and apoptosis data, ${ }^{[19]} 7 \mathrm{mM}$ DPD dose was detected for gene expression study. After $7 \mathrm{mM}$ DPD treatment, relative ratios of MAP2K3, MAP3K7, and MAPK8 genes were 7.5, 42.02, and 98.5, respectively. Relative expressions of MAP2K3, MAP3K7, and MAPK8 genes when compared to untreated cells were 2.9, 5.4, and 6.6, respectively (Table 1). Eventually, DPD treatment increased expressions of MAP2K3, MAP3K7 and MAPK8 genes in terms of mRNA levels.

\section{DISCUSSION}

Barranco and Eckhert ${ }^{[10]}$ demonstrated that boric acid treatment reduces proliferation and viability in prostate cancer and immortalizes prostate epithelial cells. However, decreasing proliferation and viability of prostate cancer and non-tumorigenic prostate cells are not

Table 1. Expressions of target genes compared to control group

\begin{tabular}{lcccc}
\hline Genes & $\begin{array}{c}\text { Ct values of DPD } \\
\text { treatment }\end{array}$ & $\begin{array}{c}\text { Ct values of non-DPD } \\
\text { treatment }\end{array}$ & $\begin{array}{c}\text { Fold Change } \\
\text { (comparing to control group) }\end{array}$ & $\begin{array}{c}\text { Log2 transformed } \\
\text { relative quantity ratio }\end{array}$ \\
\hline MAP2K3 & 25.92 & 28.94 & 7.53 & 2.9 \\
MAP3K7 & 29.5 & 35.0 & 42.02 & 5.4 \\
MAPK8 & 28.27 & 35.0 & 98.58 & 6.6 \\
GAPDH (housekeeping) & 23.32 & 22.99 & 0.73 & -0.43 \\
$\begin{array}{l}\text { 18S Ribosomal RNA } \\
\text { (housekeeping) }\end{array}$ & 20.28 & 20.27 & 0.92 & -0.12 \\
\hline
\end{tabular}

DPD: Disodium pentaborate decahydrate; MAP2K3: Mitogen-activated protein kinase kinase 3; GAPDH: Glyceraldehyde 3-phosphate dehydrogenase; RNA: Ribonucleic acid; $18 \mathrm{~S}$ ribosomal RNA and GAPDH genes were used as housekeeping. Disodium pentaborate decahydrate untreated DU-145 cells was used as external normalization factor. 
correlated with apoptosis mechanism. Barranco and Eckhert ${ }^{[11]}$ suggested that the reason for the decrease in proliferation of prostate cancer cells is associated with a reduction in cyclins and also the phosphorylated ERK and MEK proteins. Prolonged boric acid treatment changes the morphology of DU-145 prostate cancer cells depending on senescence and alteration of the actin cytoskeleton in DU-145 prostate cancer cells. ${ }^{[11,12]}$ According to our previous study, it was observed that DU-145 prostate cancer cells are sensitive to DPD treatment. ${ }^{[19]}$ Decreasing cell proliferation and viability in DU-145 prostate cancer cells were detected with increasing DPD concentrations. ${ }^{[19]} 7 \mathrm{mM}$ DPD dose decreases cell proliferation in more than $50 \%$ of DU- 145 prostate cancer cell line and increases apoptosis without any time conditions at 24,48 , and 72 hours. ${ }^{[19]}$ Because of this, $7 \mathrm{mM}$ DPD dose at 24 hour was used to detect expressions of MAP2K3, MAP3K7 and MAPK8 genes. Contrary to the effect of boric acid, ${ }^{[10]}$ apoptosis in DU-145 prostate cancer was observed after DPD treatments. ${ }^{[19]}$

Apoptosis might be associated with different chemical structures between DPD and boric acid. Besides this, increasing expressions of MAP2K3, MAP3K7, and MAPK8 genes might be related to apoptosis in DU-145 prostate cancer cells after DPD treatment. It is known that MAP2K3 is downregulated in immortal human breast epithelial cells and upregulation of MAP2K3 expression provides cell senescence. ${ }^{[13]}$ Interestingly, decreased expression of MAP2K3 was detected in invasive breast ductal carcinomas, but not in non-cancerous human breast tissues. ${ }^{[13]}$ MAP2K3 and MAP2K6 mediated phosphorylation leads to induction of $\mathrm{p} 38 \alpha$ signaling pathway depending on activation of activating transcription factor 2 (ATF-2) in MCF-10A breast cells. ${ }^{[14]}$ This induction causes caspase- 3 dependent anoikis of the detached cells. ${ }^{[14]}$ Activation of p38 $\alpha$ MAPK signaling pathway and upstream mediators, which are MAP2K3 and MAP2K6, induces apoptosis mechanism in DU-145 prostate cancer cells. ${ }^{[15]}$ In another study, it was found that isochaihulactone causes cell cycle arrest at G2/M phase and induces apoptosis in LNCaP prostate cancer cells. ${ }^{[20]}$ Regulation of cell cycle and apoptosis is associated with downregulation of expressions of the checkpoint proteins and upregulation of p53 and p21 levels. ${ }^{[20]}$ Also, it was shown that isochaihulactone treatment on LNCaP prostate cancer cells increases JNK1 (MAPK8) and JNK2 phosphorylation. ${ }^{[20]}$ Different studies emphasized that phosphorylation of MAPK8 contributes to caspase-dependent apoptosis in DU145 prostate cancer cell line. ${ }^{[18,21]}$ MAP3K7 gene is located at 6q15; however, 6q14-21 is commonly deleted in prostate cancers. Deletion of MAP3K7 gene is associated with advanced tumor stage, high Gleason grade, lymph node metastasis, and early biochemical recurrence in prostate cancer. ${ }^{[16,17]}$ MAP3K7 is thought to function as a tumor suppressor gene due to loss of one allele. ${ }^{[16,17]}$ In this study, increased expression profiles of MAP2K3, MAP3K7 and MAPK8 genes were observed after $7 \mathrm{mM}$ DPD treatment. The rate of increase in the expression levels of MAP2K3, MAP3K7 and MAPK8 were measured as 2.9, 5.4, and 6.6, respectively. Expression of MAP3K7 gene which is a candidate tumor suppressor gene for prostate cancer was increased by DPD treatment. In addition, the reason for apoptosis might be associated with high expression levels of the MAP2K3, MAP3K7 and MAPK8 genes after DPD treatment and these defined genes might regulate apoptosis via $\mathrm{p} 38 \alpha$ and JNK signaling pathway. Consequently, we suggest that DPD may be an important agent in the treatment of prostate cancer by inducing apoptosis against mitogenic and environmental stress.

\section{Acknowledgments}

We would like to thank the National Boron Research Institute, BOREN for providing Disodium Pentaborate Decahydrate.

\section{Declaration of conflicting interests}

The authors declared no conflicts of interest with respect to the authorship and/or publication of this article.

\section{Funding}

This research was supported with grants (2009-92 and 2010-91) from BAP projects by Celal Bayar University.

\section{REFERENCES}

1. Siegel R, Naishadham D, Jemal A. Cancer statistics, 2012. CA Cancer J Clin 2012;62:10-29.

2. Siegel R, DeSantis C, Virgo K, Stein K, Mariotto A, Smith $\mathrm{T}$, et al. Cancer treatment and survivorship statistics, 2012. CA Cancer J Clin 2012;62:220-41.

3. Dehm SM, Tindall DJ. Molecular regulation of androgen action in prostate cancer. $\mathrm{J}$ Cell Biochem 2006;99:333-44. 
4. Kohli M, Tindall DJ. New developments in the medical management of prostate cancer. Mayo Clin Proc 2010;85:77-86.

5. Basu S, Tindall DJ. Androgen action in prostate cancer. Horm Cancer 2010;1:223-8.

6. Rathkopf D, Scher HI. Androgen receptor antagonists in castration-resistant prostate cancer. Cancer J 2013;19:43-9.

7. Rove KO, Crawford ED. Androgen annihilation as a new therapeutic paradigm in advanced prostate cancer. Curr Opin Urol 2013;23:208-13.

8. Barranco WT, Hudak PF, Eckhert CD. Evaluation of ecological and in vitro effects of boron on prostate cancer risk (United States). Cancer Causes Control 2007;18:71-7.

9. Cui Y, Winton MI, Zhang ZF, Rainey C, Marshall J, De Kernion JB, et al. Dietary boron intake and prostate cancer risk. Oncol Rep 2004;11:887-92.

10. Barranco WT, Eckhert CD. Boric acid inhibits human prostate cancer cell proliferation. Cancer Lett 2004;216:21-9.

11. Barranco WT, Eckhert CD. Cellular changes in boric acid-treated DU-145 prostate cancer cells. Br J Cancer 2006;94:884-90.

12. McAuley EM, Bradke TA, Plopper GE. Phenylboronic acid is a more potent inhibitor than boric acid of key signaling networks involved in cancer cell migration. Cell Adh Migr 2011;5:382-6.

13. Jia M, Souchelnytskyi N, Hellman U, O'Hare M, Jat PS, Souchelnytskyi S. Proteome profiling of immortalization-to-senescence transition of human breast epithelial cells identified MAP2K3 as a senescence-promoting protein which is downregulated in human breast cancer. Proteomics Clin Appl 2010;4:816-28.

14. Wen HC, Avivar-Valderas A, Sosa MS, Girnius N, Farias EF, Davis RJ, et al. p38 $\alpha$ Signaling Induces
Anoikis and Lumen Formation During Mammary Morphogenesis. Sci Signal 2011;4:34.

15. Permpongkosol S, Wang JD, Takahara S, Matsumiya $\mathrm{K}$, Nonomura N, Nishimura K, et al. Anticarcinogenic effect of FTY720 in human prostate carcinoma DU145 cells: modulation of mitogenic signaling, FAK, cell-cycle entry and apoptosis. Int $\mathrm{J}$ Cancer 2002;98:167-72.

16. Kluth M, Hesse J, Heinl A, Krohn A, Steurer S, Sirma $\mathrm{H}$, et al. Genomic deletion of MAP3K7 at 6q12-22 is associated with early PSA recurrence in prostate cancer and absence of TMPRSS2:ERG fusions. Mod Pathol 2013;26:975-83.

17. Liu W, Chang BL, Cramer S, Koty PP, Li T, Sun $\mathrm{J}$, et al. Deletion of a small consensus region at $6 \mathrm{q} 15$, including the MAP3K7 gene, is significantly associated with high-grade prostate cancers. Clin Cancer Res 2007;13:5028-33.

18. Guo J, Zhu T, Xiao ZX, Chen CY. Modulation of intracellular signaling pathways to induce apoptosis in prostate cancer cells. J Biol Chem 2007;282:24364-72.

19. Korkmaz M, Avci CB, Gunduz C, Aygunes D, Erbaykent-Tepedelen B. Disodium pentaborate decahydrate (DPD) induced apoptosis by decreasing hTERT enzyme activity and disrupting F-actin organization of prostate cancer cells. Tumor Biol 2014;35:1531-8.

20. Chiu SC, Wang MJ, Yang HH, Chen SP, Huang SY, Chen YL, et al. Activation of NAG-1 via JNK signaling revealed an isochaihulactone-triggered cell death in human LNCaP prostate cancer cells. BMC Cancer 2011;11:146.

21. Jiang C, Wang Z, Ganther H, Lü J. Distinct effects of methylseleninic acid versus selenite on apoptosis, cell cycle, and protein kinase pathways in DU145 human prostate cancer cells. Mol Cancer Ther 2002;1:1059-66. 